\title{
Reducing Solar Heat Gain during Winter: The Role of White Bark in Northern Deciduous Trees
}

\author{
TIM J. KARELS ${ }^{1,2}$ and RUDY BOONSTRA ${ }^{1}$
}

(Received 24 October 2001; accepted in revised form 24 October 2002)

\begin{abstract}
Deciduous tree species throughout the boreal forest of North America have lighter-coloured bark than do species restricted to more southern forests. We tested the hypothesis that light-coloured bark minimizes the thawing and freezing of cambium tissue during winter that could contribute to sunscald injury. During mid-winter, maximum midday cambium temperatures of south-exposed bark of white birch (Betula papyrifera Marsh.) near Timmins, Ontario, were higher for brownpainted bark $\left(+1.6{ }^{\circ} \mathrm{C}\right)$ than for natural bark $\left(-9.4{ }^{\circ} \mathrm{C}\right)$ and white-painted bark $\left(-12.1^{\circ} \mathrm{C}\right)$. Rates of temperature decrease after trees were shaded at midday were more rapid for brown-painted bark $\left(0.06{ }^{\circ} \mathrm{C} / \mathrm{min}\right)$ than for natural bark $\left(0.03{ }^{\circ} \mathrm{C} / \mathrm{min}\right)$ and whitepainted bark $\left(0.03{ }^{\circ} \mathrm{C} / \mathrm{min}\right)$. When stems of white birch, trembling aspen (Populus tremuloides Michx.), yellow birch (B. alleghaniensis Britton), and largetooth aspen (P. grandidentata Michx.) were illuminated and subsequently shaded at $-10{ }^{\circ} \mathrm{C}$ ambient air temperature, maximum cambium temperatures and rates of cambium cooling increased with decreasing measures of whiteness. For trembling aspen in the southwest Yukon, we found that after two years, brown-painted trees had a higher incidence $(35 \%)$ of wounding that resembled sunscald injury than did white-painted trees $(2.5 \%)$ and natural trees $(4.5 \%)$. Therefore, we suggest that light-coloured bark reduces the risk of winter sunscald injury, probably by protecting the cambium from solar heat gain in subfreezing temperatures. This physical mechanism for reducing sunscald risk may explain why the deciduous trees at the northern limit of tree growth are those with highly reflective bark.
\end{abstract}

Key words: bark colour, white birch, cambium temperatures, trembling aspen, sunscald, boreal forest, deciduous trees

RÉSUMÉ. Dans toute la forêt boréale de l'Amérique du Nord, les arbres à feuilles caduques ont une écorce plus claire que celle des espèces dont l'habitat est limité aux forêts plus au sud. On a testé l'hypothèse selon laquelle, au cours de l'hiver, l'écorce claire minimise le gel-dégel du cambium qui pourrait contribuer à une blessure d'insolation. Au milieu de l'hiver, à midi, près de Timmins, en Ontario, la température maximale du cambium de l'écorce orientée au sud du bouleau à papier (Betula papyrifera Marsh.) était plus élevée pour l'écorce peinte en brun $\left(+1,6{ }^{\circ} \mathrm{C}\right)$ que pour l'écorce naturelle $\left(-9,4{ }^{\circ} \mathrm{C}\right)$ et celle peinte en blanc $\left(-12,1^{\circ} \mathrm{C}\right)$. Après midi, quand les arbres étaient à l'ombre, le taux de baisse de la température était plus rapide pour l'écorce peinte en brun $\left(0,06{ }^{\circ} \mathrm{C} / \mathrm{min}\right)$ que pour l'écorce naturelle $\left(0,03{ }^{\circ} \mathrm{C} / \mathrm{min}\right)$ et pour celle peinte en blanc $\left(0,03{ }^{\circ} \mathrm{C} / \mathrm{min}\right)$. Quand les tiges du bouleau à papier, du peuplier faux-tremble (Populus tremuloides Michx.), du bouleau jaune (B. alleghaniensis Britton), et du peuplier à grandes dents ( $P$. grandidentata Michx.) étaient éclairées et ensuite soumises à l'ombre à une température ambiante de $-10{ }^{\circ} \mathrm{C}$, plus la blancheur mesurée diminuait, plus la température maximale du cambium et son taux de refroidissement augmentaient. Pour le peuplier faux-tremble dans le sud-ouest du Yukon, on a trouvé qu'après deux ans, les arbres peints en brun avaient une plus haute fréquence (35\%) de blessures semblables à des blessures d'insolation que les arbres peints en blanc (2,5\%) et les arbres naturels (4,5\%). On suggère par conséquent que l'écorce claire réduit le risque de blessures hivernales causées par l'insolation, et ce, probablement en protégeant le cambium de l'apport de chaleur solaire par des températures inférieures au point de congélation. Ce mécanisme physique qui permet de réduire le risque d'insolation pourrait expliquer pourquoi les arbres à feuilles caduques situés à la limite septentrionale des arbres sont ceux dotés d'une écorce très réfléchissante.

Mots clés: couleur de l'écorce, bouleau à papier, température du cambium, peuplier faux-tremble, insolation, forêt boréale, arbres à feuilles caduques

Traduit pour la revue Arctic par Nésida Loyer.

\section{INTRODUCTION}

In North America, only four deciduous tree species extend their distribution to the northern limit of tree growth: white birch, Alaska white birch (B. neoalaskana
Sarg.), trembling aspen, and balsam poplar ( $P$. balsamifera L.) (Sakai and Weiser, 1973; Arno and Hammerly, 1984). These species all possess bark that is thin, smooth, and coloured from light grey to white (Harlow and Harrar, 1958; Grant and Thompson, 1975;

\footnotetext{
${ }^{1}$ Division of Life Sciences, University of Toronto at Scarborough, 1265 Military Trail, Scarborough, Ontario M1C 1A4, Canada

${ }^{2}$ Present address: Centre for Biodiversity Research, University of British Columbia, 6270 University Blvd., Vancouver, British Columbia V6T 1Z4; karels@zoology.ubc.ca

(C) The Arctic Institute of North America
} 
Farrar, 1995). The prevalence of light-coloured bark in northern deciduous trees suggests that it may serve as an adaptation for living in cold environments. Bark colour influences the temperature of bark tissue when the bark is exposed to sunlight (Harvey, 1923b). Injuries caused by temperature fluctuations in winter may select for trees with lighter barks.

Winter-related injuries in northern trees that are caused by fluctuations in tree temperatures include frost cracking, xylem cavitation, and sunscald. Frost cracks are splits in the radial-longitudinal plane of a stem caused by "frost shrinkage," which occurs when the outer layer of a tree is colder and contracts faster than the core (Kubler, 1983, 1987). As the contracting outer layer presses on the core, it exceeds its elastic limit and splits (Vasil'yev, 1956; Kramer and Koslowski, 1960). This winter injury is not affected by bark colour since solar radiation warms only the south side of the tree, and the highly insulative wood protects the core from warming (Derby and Gates, 1966).

Cavitation is a loss of sap conduction when xylem conduits become embolized (filled with air) (Magnani and Borghetti, 1995). Embolism can be produced by low water potential during drought (Kolb and Davis, 1994) or during freeze-thaw events when bubbles of dissolved gases coming out of solution during freezing later nucleate cavitation after thawing (Sperry and Sullivan, 1992). Winter embolism can potentially reduce sap flow in spring, producing branch dieback (Sperry, 1993). However, many temperate trees demonstrate mechanisms for avoiding (Picea, Larix, Abies spp.), repairing (Betula, Alnus spp.), or tolerating (Quercus, Populus spp.) winter embolism (Sperry et al., 1994). Bark colour may influence the frequency of freezing and thawing of xylem fluids during winter thus potentially leading to cavitation. However, there is little evidence that cavitation has serious negative effects owing to the robustness of xylem vessels (Canny, 1998).

Sunscald appears as lesions or cankers on the south sides of trees, the result of direct sun exposure during winter and early spring (Harvey, 1923a, b); it eventually causes the bark to become loose and fall off (Huberman, 1943). Sudden thawing, increased sap flow, and cessation of dormancy caused by elevated temperatures on the sun-exposed sides of trees do not produce sunscald damage (Huberman, 1943). Sunscald damage is thought to occur when obstruction of sunlight (e.g., by movement of clouds or movement of sun behind adjacent trees or nearby hills) refreezes cambium tissue temporarily thawed by insolation, causing cellular death (Huberman, 1943; Kramer and Koslowski, 1960; Levitt, 1980; Tatler, 1989). Sunscald has been reported in basswood (Tilia americana L.), Manitoba maple (Acer negundo L.), black walnut (Juglans nigra L.) (Litzow and Pellett, 1983), black birch (B. lenta L.) (Tatler, 1989), yellow poplar (Liriodendron tulipifera L.), yellow birch (Godman, 1959), and white pine (Pinus strobes L.) (Huberman, 1943). We have not found reports of individual tree death associated with sunscald, but damage to bark that extends to living cambium tissue may act as an entry point for pathogens, which may indirectly lead to tree death (Boyce, 1961). We suggest that northern deciduous trees have evolved reflective bark to reduce the risk of winter sunscald.

If there is a selective advantage of white bark in reducing sunscald, we predict the following: 1) the cambium under white bark will experience smaller temperature fluctuations than cambium under darkercoloured bark during normal winter conditions; 2) rates of refreezing of the cambium will be proportional to the temperature differential between cambium and ambient; and 3) sunscalding will be more frequent on trees with dark-coloured bark than on trees with white bark. We tested these predictions with a series of field and laboratory experiments.

\section{METHODS}

\section{Field Study 1: Cambium Temperature of White Birch}

To examine the effect of bark colour on temperature change in natural winter conditions, we selected eight unshaded trees $($ diameter $=15.4 \pm 1.4 \mathrm{~cm}$ ) from a pure stand of white birch on the north edge of a clearing approximately $35 \mathrm{~km}$ south of Timmins, Ontario $\left(48^{\circ} \mathrm{N}\right.$, $81^{\circ} \mathrm{W}$, elevation $\left.=295 \mathrm{~m}\right)$. The average maximum and minimum February temperatures in Timmins are $-8.8^{\circ} \mathrm{C}$ and $-22.3^{\circ} \mathrm{C}$ respectively (Environment Canada, 1982). Continuous snow cover occurs from November to April. On the day of this experiment (15 February 1993), the sky was cloudless, temperatures ranged from $-25^{\circ} \mathrm{C}$ to $-14^{\circ} \mathrm{C}$, snow cover was $100 \%$, and daybreak and sunset were at $0730 \mathrm{~h}$ and $1747 \mathrm{~h}$, respectively.

Each tree stem received three colour treatments around its entire circumference in successive $60 \mathrm{~cm}$ vertical lengths, starting $20 \mathrm{~cm}$ above the snow: natural (unpainted), white latex paint, and dark brown latex paint. White paint served as a control for the influence of paint application on cambium temperature. To control for location, we reversed the order of colour treatment. On half the trees, the order (from bottom up) was brown, white, natural; for the rest, it was natural, white, brown. White thermocouple wire (Tex-Tex-20 Type K wire, Thermo Electric Canada, Ltd., Brampton, Ontario) was installed on the north and south sides of the tree in the cambium under each treatment within a $3.2 \mathrm{~mm}$ diameter hole that was drilled for $5 \mathrm{~cm}$ nearly vertical along the inside surface of the bark. Thermocouples protruding $5 \mathrm{~cm}$ from the north surface of each tree were also installed to monitor ambient temperature in the shade. Temperatures were read (2455 series digital thermometer, Yokogawa Electric Corporation, Tokyo, Japan) every hour over a seven-hour period from $1000 \mathrm{~h}$ to $1700 \mathrm{~h}$. Trees were no longer exposed to sunlight after $1700 \mathrm{~h}$, and one last temperature reading was therefore taken at $1730 \mathrm{~h}$. 


\section{Field Study 2: Cooling Rates of White Birch}

To examine the rate of cambium temperature change after shading, we shaded four of the above trees with reflective silver plastic sheeting $(1 \times 2 \mathrm{~m})$ spaced $0.5 \mathrm{~m}$ from each tree at 12:00 noon on the cloudless day of 18 February 1993. Average diameter of these four trees was $14.9 \pm 1.7 \mathrm{~cm}$. Ambient air temperature from one thermocouple and cambium temperatures from the three colour treatments on all four trees were determined at shading, and cambium temperature was measured again $30 \mathrm{~min}$ later to estimate the rate of cooling.

\section{Laboratory Study: Cooling Rates}

In a $-10^{\circ} \mathrm{C}$ freezer, we measured the cambium cooling rates of nine stem sections from four tree species. These sections came from white birch, trembling aspen, and two congeneric species with more southerly distributions, yellow birch and largetooth aspen ( $P$. grandidentata Michx.) (Farrar, 1995). All nine undamaged stem sections $(10 \mathrm{~cm}$ diameter $\times 60 \mathrm{~cm}$ length) were cut while frozen from separate trees during late February, three weeks before the experiment. To minimize moisture loss, the stems were sealed with paraffin at both ends, encased in plastic, and kept frozen until the experiment. Only samples shipped from the Yukon were not frozen for a period of five days while in transit. Four white birch stems were taken from the deciduous forest region in southern Ontario, one painted brown, one painted white, one unpainted, and one lichencovered. Three trembling aspen stems were used; two were from the southwest Yukon (one green, the other silver-grey) and one was from southern Ontario (chalkywhite). The largetooth aspen and the yellow birch samples were from southern Ontario. Two thermocouples were installed in the cambium on opposite sides of each stem, using the same technique described above.

All stems were acclimated to the freezer for two days before the start of the experiment. Sunlight was simulated by illuminating each stem with a broad-spectrum metal filament lamp (General Electric 300-W Halogen) placed $1 \mathrm{~m}$ from the stem. Each experimental stem was illuminated for $30 \mathrm{~min}$; then the light was turned off, and the temperatures were recorded at 5 and 10 min thereafter from both the thermocouple on the illuminated side and that on the dark side. Temperature changes were recorded as the difference between the illuminated side and the dark side to control for changes in temperature not associated with illumination. The entire procedure was repeated four times for each stem. Cooling was estimated to be linear over a 5 min interval.

\section{Field Study 3: Tree Damage}

To examine the influence of bark colour on frequency of wounding, we manipulated stem colour of trembling aspen within a stand near Kluane Lake in the southwest Yukon Territory, Canada $\left(61^{\circ} \mathrm{N}, 138^{\circ} \mathrm{W}\right.$, elevation $\left.=850 \mathrm{~m}\right)$ on
6-7 September 1993. Forty trembling aspen $50 \mathrm{~m}$ apart along two transects were painted brown over the entire circumference of a $1 \mathrm{~m}$ section of the stem $1.5 \mathrm{~m}$ above the ground, which is $0.5 \mathrm{~m}$ above the maximum annual depth of snow accumulation. Oil-based paint was used in this study because long-term application of latex paint injures trees (Mosher and Cool, 1974). Each painted tree was paired with an unmanipulated tree of approximately the same diameter and within approximately $10 \mathrm{~m}$. To control for paint application, we painted 22 trees white. All trees in this study were $10-20 \mathrm{~cm}$ in diameter, had no visible wounds or blemishes, and were shaded by the trembling aspen foliage during summer, so that summer heat stress was not a factor in our study. Two years later, on 15 August 1995, the south-facing sides of all trees were examined and recorded as either wounded or not wounded. Wounds potentially associated with sunscalding were identified as cracks in the bark that were separate from branch nodes. These cracks are not oriented in any particular direction. In contrast, frost cracks are vertical splits that penetrate deep into the wood (Kubler, 1983).

\section{Whiteness Index}

All experimental trees (62 B. papyrifera in Ontario and 56 P. tremuloides in Yukon, plus the 9 tree sections used in the laboratory) were assessed for whiteness. We use the term "whiteness" as a proxy for reflectivity. Since we did not have access to equipment capable of measuring reflectivity of all wavelengths, we developed a whiteness index as a crude relative measurement of reflectivity. The whiteness index describes only visible wavelength reflectivity and therefore assumes that reflection of other high-energy wavelengths (i.e., infrared) is correlated to reflection of visible light. To develop our whiteness index, we used a $35 \mathrm{~mm}$ single-lens reflex camera with a $50 \mathrm{~mm}$ f1.8 lens and colour transparency film (Fujichrome 100 ASA) to take photographs of each sample in which half of the image was bark and the other half contained a matte-finish photographic grey card (18\% grey). Since internal camera light meters measure all exposures as relative to $18 \%$ grey, we measured film exposure from the grey card, using the camera's internal spot meter to ensure proper exposure of bright surfaces (i.e., white bark). Each transparency was projected in a dark room (i.e., no external light sources), and the intensity of light passing through the image of the grey card and through the image of the bark was measured (in foot-candles) using an illumination meter (Model 756, Weston Instruments, Division of Daystrom, Inc., Newark, New Jersey, U.S.A.). The distance from projector to screen was set so that an unexposed slide did not cast any light on the screen, as measured by the illumination meter. This was done separately for each film. Although the absolute light measurement taken from the bark image may provide a good index of whiteness, we used the measurement of light being transmitted through the grey card image as a control for possible differences in exposure, film stock, or 
film development. The ratio of the light intensity transmitted through the grey card image to the light transmitted through the bark image was considered to approximate the ratio of light reflected from the grey card to the light reflected from the bark. Therefore the whiteness index (W) of the bark was calculated as follows:

$$
\mathrm{W}=\frac{18 \times \mathrm{B}}{\mathrm{G}}
$$

where B was the intensity of light transmitted through the bark image and $\mathrm{G}$ was the intensity of light transmitted through the grey card image. This yields an index of 0 (total black) to 1 (total white). However, we do not interpret these values as absolute (i.e., $0.5=50 \%$ reflectivity of visible light) but rather as relative measures of reflectance of visible light.

\section{Analysis}

All statistical procedures were conducted according to Zar (1984). Cochran's test for homogeneity of variance (Winer, 1971) was performed prior to ANOVA, as recommended by Day and Quinn (1989). Cambium temperature and whiteness values from white birch were transformed using a Box-Cox transformation (Krebs, 1999) and logarithmic transformation, respectively. All ANOVAs, ANCOVAs, and Tukey-Kramer post-hoc tests were performed using SuperANOVA (Gagnon et al., 1991). Repeated measures ANOVA was used to analyze cambium temperatures over time in Field Study 1, with bark colour (brown, white, natural) and exposure (north, south) as main factors and temperature as the repeated measure where time is a covariate. Log-linear models to test frequency of wounding in Field Study 3 and linear regressions in the laboratory study were performed with StatView (SAS Institute Inc., 1998). Means are expressed with \pm 1 S.E.

\section{RESULTS}

\section{Field Study 1: Cambium Temperature of White Birch}

During the course of this experiment, ambient air temperature increased from $-19^{\circ} \mathrm{C}$ to a maximum of $-14^{\circ} \mathrm{C}$ (Fig. 1). Cambium temperatures for all colour treatments on both north- and south-exposed bark of white birch trees also increased, but at greater rates for the south-exposed bark (repeated measures ANOVA, time (covariate) $\times$ exposure: $\mathrm{F}_{8,336}=3.3, p<0.001$ ) (Fig. 1). Bark colour had different effects on the rates of temperature change in the cambium for north- and south-exposed bark (repeated measures ANOVA, time (covariate) $\times$ bark colour: $\mathrm{F}_{16,336}$ $=1.3, p<0.001)$ (Fig. 1). The greatest effect on cambium temperature was produced by brown-painted bark on the south-facing sides of birch at $1300 \mathrm{~h}$, when cambium temperature reached $+1.6 \pm 0.8^{\circ} \mathrm{C}$, exceeding ambient

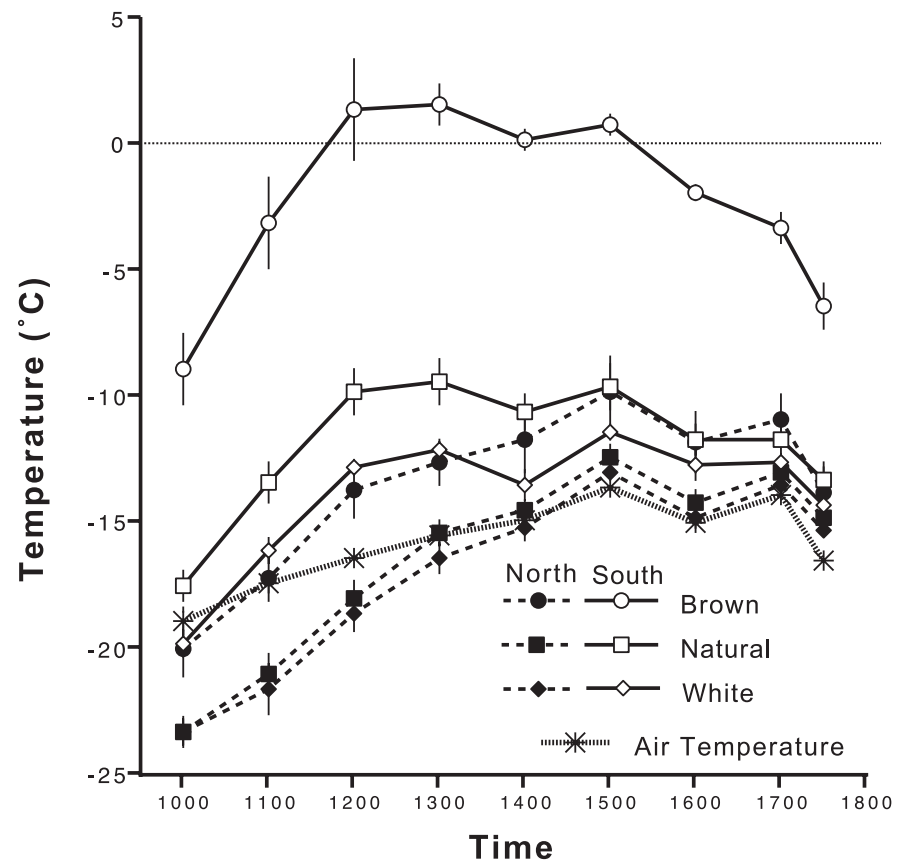

FIG. 1. Cambium temperatures of eight white birch trees under three colour treatments (brown-painted bark, white-painted bark, and unpainted natural bark), measured on the southern side. Ambient temperature was measured on the north face of each tree. Invisible S.E. bars are smaller than the point. The experiment was conducted on a cloudless day, 15 February 1993, at Timmins, Ontario, Canada.

temperature by $17.8^{\circ} \mathrm{C}$ (Fig. 1). Paint itself did not increase temperatures because white-painted bark on both exposures maintained lower cambium temperatures throughout the study than the other two bark colours (Fig. 1). On the south-exposed bark at $1300 \mathrm{~h}$, the cambium temperature underneath natural bark $\left(-9.4 \pm 0.9^{\circ} \mathrm{C}\right)$ was $2.7^{\circ} \mathrm{C}$ higher than that underneath white-painted bark $\left(-12.1 \pm 0.28^{\circ} \mathrm{C}\right)$ and $11^{\circ} \mathrm{C}$ lower than that underneath brown-painted bark.

\section{Field Study 2: Cooling Rates of White Birch}

At time of shading, ambient air temperature was $-16^{\circ} \mathrm{C}$ and the initial temperatures of the treatments were as follows: Brown $=2.8 \pm 3.4^{\circ} \mathrm{C}$, White $=-13.4 \pm 1.0^{\circ} \mathrm{C}$, and Natural $=-10.1 \pm 1.1^{\circ} \mathrm{C}$. Brown-painted bark showed the greatest drop in cambium temperature over the $30 \mathrm{~min}$ period after shading $\left(1.8 \pm 1.8^{\circ} \mathrm{C}\left[0.06^{\circ} \mathrm{C} / \mathrm{min}\right]\right)$, followed by natural bark $\left(1.0 \pm 1.8^{\circ} \mathrm{C}\left[0.03^{\circ} \mathrm{C} / \mathrm{min}\right]\right)$ and whitepainted bark $\left(1.0 \pm 0.6^{\circ} \mathrm{C}\left[0.03^{\circ} \mathrm{C} / \mathrm{min}\right]\right)$. Differences in rates of temperature change among the treatments were not significant (ANCOVA: $\mathrm{F}_{2,6}=0.3, p=0.7$ ) and were not dependent on initial temperature at time of shading (ANCOVA: $\mathrm{F}_{1,6}=2.1, p=0.2$ ).

\section{Laboratory Study: Cooling Rates}

Temperature increase under illumination was negatively associated with bark whiteness (linear regression: $r^{2}$ $=0.93$, d.f. $=8, p<0.001)($ Fig. $2 \mathrm{a})$. For every 0.1 increase 

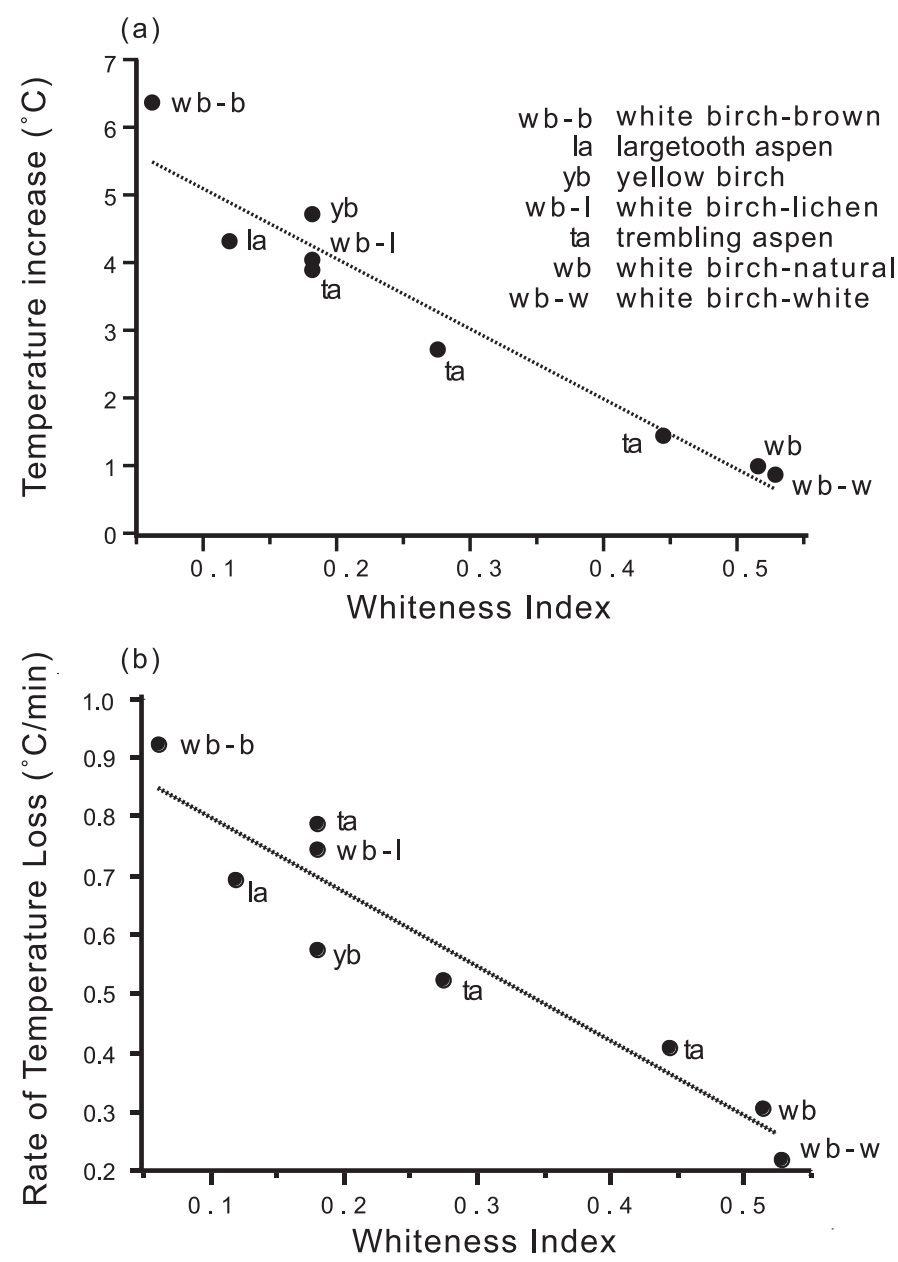

FIG. 2. (a) Cambium temperature increase after $30 \mathrm{~min}$ of illumination (regression: $\mathrm{y}=-10.4 \mathrm{x}+6.14, r^{2}=0.93$ ) of nine cut stems with different whiteness values at a constant ambient temperature of $-10^{\circ} \mathrm{C}$. (b) Rate of temperature loss after removal of light following 30 minutes of illumination (regression: $\mathrm{y}=-1.24 \mathrm{x}+0.92, r^{2}=0.89$ ).

in whiteness, there was an associated $1^{\circ} \mathrm{C}$ decrease in cambium temperature. Since there was very little variation among the four trials conducted because of the controlled environment, standard errors are not presented in Figure 2 (all S.E.s per sample $\leq 0.3^{\circ} \mathrm{C}$ ).

The rate of temperature loss after light was removed was negatively associated with bark whiteness (linear regression: $r^{2}=0.89$, d.f. $=8, p<0.001$ ) (Fig. 2b). For every 0.1 increase in whiteness, there was an associated $0.1^{\circ} \mathrm{C} / \mathrm{min}$ decrease in the cooling rate.

\section{Field Study 3: Tree Damage}

Wounding varied from small cracks in the bark to visible separation of the bark from the tree. Vertical splits in the woody tissue were not observed in any of the trees we examined; therefore, frost cracking was not associated with colour treatments. The wounding that we observed differed among treatments $(G=19.3$, d.f. $=2, p<0.001)$ (Table 1). The frequency of wounding in brown-painted trembling aspen was significantly greater than that in
TABLE 1. Percentage of trembling aspen stems showing wounding after two years of bark colour manipulation in the southwest Yukon.

\begin{tabular}{lcc}
\hline \hline Bark Treatment & Wounded $(\%)$ & $\mathrm{N}$ \\
\hline Brown paint & 35.0 & 40 \\
Natural & 2.5 & 40 \\
White paint & 4.5 & 22 \\
\hline \hline
\end{tabular}

unpainted trembling aspen $(G=16.06$, d.f. $=1, p<0.001)$. The frequency of wounding of white-painted trees was similar to that of unpainted trees $(G=0.18$, d.f. $=1, p=$ $0.67)$; therefore, damage was not an artifact of the paint itself.

\section{Whiteness Indices}

The average whiteness index of white birch from northern Ontario was $0.53 \pm 0.02(\mathrm{~N}=62$, range $=0.21$ to 1$)$ and was similar to that of trembling aspen $(0.51 \pm 0.03, \mathrm{~N}=56$, range $=0.04$ to 1$)$. Lichen or fungal cover, age of the tree, and scars from prior damage contributed to the low whiteness values that we recorded for some trees. Our method has limitations, and several trees ( 1 birch and 2 aspen) had very high whiteness values $(\mathrm{W}=1)$. We interpret this not as complete reflectance of all visible light, but only as very white bark relative to the rest of the specimens we measured. However, our index does provide a suitable measure of the absorption/reflectance of high-energy wavelengths. The high negative correlation between whiteness and cambium temperature increase $\left(r^{2}=0.93\right)$ as described in the laboratory study above indicates either that visible light contributes most of the heat energy absorbed by the bark, or that our index of visible light reflectance is highly correlated with the reflectance of other high-energy wavelengths (e.g., infrared).

\section{DISCUSSION}

During winter, bark colour appears to play an important role in the thermal dynamics of the cambium of deciduous trees. In comparison with light-coloured bark, darkcoloured bark was associated with increased cambium temperatures (Figs.1 and 2a) and greater rates of cooling (Fig. 2b) in both our field studies and our laboratory experiment. Furthermore, after two years of manipulation, trembling aspen trees with dark-coloured bark had a greater incidence of wounding than trembling aspen with lightcoloured bark (Table 1). We suggest that sunscald injury may be an important selective mechanism for lightcoloured bark for trees in the northern boreal forests.

Cooling rates in our laboratory study far exceeded those we measured in Field Study 2 despite the warmer conditions in the freezer $\left(-10^{\circ} \mathrm{C}\right.$ in the freezer, compared with $-16^{\circ} \mathrm{C}$ in field). As an example, we measured a cooling rate 
of $0.9^{\circ} \mathrm{C} / \mathrm{min}$ for brown-painted birch in the laboratory experiment and a rate of $0.03^{\circ} \mathrm{C} / \mathrm{min}$ for brown-painted birch in the field experiment. Although we do not know exactly why these rates are so different, we suggest several possible reasons why these measurements are not comparable. First, the samples in the laboratory were approximately one-third smaller in diameter than those in the field, and they were $60 \mathrm{~cm}$ lengths rather than whole trees. Therefore, laboratory samples had $50 \%$ greater surface area per volume than did field samples, not including the exposed ends in the laboratory samples. Second, we had complete control over all light sources in the laboratory setting, while in the field, setting trees were still exposed to scattered light reflected from the snow (and possibly from our shading material, which was highly reflective on both sides to avoid radiation of heat toward the tree from the shading material itself). Nevertheless, both experiments demonstrate that trees with dark-coloured bark experience greater heat gain in their cambium under illumination and greater rates of heat loss after exposure to light ceases.

Low temperature extremes may not be a factor limiting the northward distribution of plants. Freezing resistance in plants is often effective at temperatures lower than the annual minimum temperatures normally encountered (Sakai and Weiser, 1973). For example, many species of conifers and deciduous trees, if acclimated slowly, can survive temperatures as low as $-80^{\circ} \mathrm{C}$ (Sakai and Weiser, 1973). The rate of freezing has been shown to be more important than temperature itself for the survival of some trees (Savage, 1970; Weiser, 1970). Under slow freezing conditions, a vapour pressure deficit caused by extracellular ice formation draws protoplasmic water out of the cell (Weiser, 1970), whereas under rapid freezing, protoplasmic water will freeze before migrating out of the cell (Levitt, 1980). The formation of intracellular ice is fatal (Siminovitch and Scarth, 1938; Hong and Sucoff, 1980; Hong et al., 1980) because ice crystals cause membrane destruction (Weiser, 1970; Burke et al., 1976).

Sakai and Larcher (1987) disagree that sunscald is a consequence of intracellular freezing. Instead, they argue that exposure to sun during winter dehardens plant tissue, thereby reducing its freezing tolerance. If tissue is dehardened, then sunscald will occur when plant tissue is exposed to unusually low nighttime temperatures. Although the exact mechanisms causing sunscald injury are still unresolved, sunscald is conclusively linked to elevated bark temperatures from exposure to sun during winter.

Harvey's (1923b) study and our study (Fig. 1) have demonstrated that the cambium in trees with low bark reflectivity may experience thawing from insolation under sub-zero ambient temperatures. During winter, cambium temperatures elevated above freezing may deharden, or cool at a rate sufficient to cause intracellular freezing and therefore cellular death. In our small sample of southern tree species, largetooth aspen and yellow birch, whose northerly distributions extend northward only to the southern border of the boreal forest, had lower bark reflectivity, greater temperature increases when exposed to light (Fig. 2a), and hence more rapid cooling when light was removed (Fig. 2b) than did white birch and trembling aspen, whose northerly distributions extended to the tree line in North America. These differences should be explored more thoroughly to account for the variation in bark colour of the southern tree species. It may be that the risk of sunscalding imposes limitations on the northern distributions of some deciduous tree species, and only species with white bark (i.e., white birch, trembling aspen, balsam poplar) can exist in winter conditions at high latitudes.

We do not know if the variation in whiteness values we measured for white birch and trembling aspen represents genotypic or phenotypic variation. Bark reflectivity may vary with environmental conditions over a small scale (e.g., trees on the edge of a stand compared with trees in the stand interior). Field experiments manipulating exposure of young trees by transplanting them or removing surrounding trees are required to separate sources of variation in bark colour within a population.

Sunscalding is more often associated with northern regions (Godman, 1959; Litzow and Pellett, 1983) where solar radiation, although weaker than at southern latitudes, interacts with the subfreezing temperatures and snow cover to create conditions more extreme than those experienced by southern trees. We suggest that selection for trees with lower risk of sunscald injury during winter is the reason for the dominance of whitebarked deciduous trees at northern latitudes.

\section{ACKNOWLEDGEMENTS}

We thank P. Sim for assistance in collecting our Yukon data and the Royal Ontario Museum for use of their walk-in freezer. Accommodation was provided in Timmins, Ontario, by V. Naidoo, and in the Yukon, by the Arctic Institute of North America, University of Calgary. We thank J. Svoboda for the use of the digital thermometer. Financial support was from the Division of Life Sciences, University of Toronto at Scarborough, and a grant to R. Boonstra from the Natural Sciences and Engineering Research Council of Canada. K.E. Hodges, D. Chitty, R. Turkington, and four anonymous reviewers contributed critical comments that greatly improved this manuscript. This is publication \#135 of the Kluane Boreal Forest Ecosystem Project.

\section{REFERENCES}

ARNO, S.F., and HAMMERLY, R.P. 1984. Timberline: Mountain and arctic forest frontiers. Vancouver: Douglas and McIntyre Ltd.

BOYCE, J.S. 1961. Forest pathology. New York: McGraw-Hill Book Company Inc.

BURKE, M.J., GUSTA, L.V., QUAMME, H.A., WEISER, C.J., and LI, P.H. 1976. Freezing and injury in plants. Annual Review of Plant Physiology 27:507-528. 
CANNY, M.J. 1998. Applications of the compensating pressure theory of water transport. American Journal of Botany 85: 897-909.

DAY, R.W., and QUINN, G.P. 1989. Comparisons of treatments after an analysis of variance in ecology. Ecological Monographs 54:433-463.

DERBY, R.W., and GATES, D.M. 1966. The temperature of tree trunks: Calculated and observed. American Journal of Botany 53:580-587.

ENVIRONMENT CANADA. 1982. Temperature and precipitation. Canadian climate normals 1951-1980. Ottawa: Atmospheric Environment Service.

FARRAR, J.L. 1995. Trees in Canada. Markham and Ottawa: Fitzhenry and Whiteside Ltd. and the Canadian Forest Service, Natural Resources Canada, in cooperation with Public Works and Government Services Canada.

GAGNON, J., ROTH, J., FINZER, B., HOFMANN, R., HAYCOCK, K., SIMPSON, J., and FELDMAN, D. 1991. SuperANOVA. Berkeley, California: Abacus Concepts, Inc.

GODMAN, R.M. 1959. Winter sunscald of yellow birch. Journal of Forestry 57:368-369.

GRANT, W.F., and THOMPSON, B.K. 1975. Observations on Canadian birches, Betula cordifolia, B. neoalaskana, B. populifolia, B. papyrifera, and B. caerulea. Canadian Journal of Botany 53:1478-1490.

HARLOW, W.M., and HARRAR, E.S. 1958. Textbook of dendrology. New York: McGraw-Hill Book Company Inc.

HARVEY, R.B. 1923a. Cambial temperatures of trees in winter and their relation to sunscald. Ecology 4:261-265.

- - $.1923 \mathrm{~b}$. Relation of the color of bark to the temperature of the cambium in winter. Ecology 4:391-394.

HONG, S.G., and SUCOFF, E. 1980. Units of freezing of deep supercooled water in woody xylem. Plant Physiology 66: $40-45$.

HONG, S.G., SUCOFF, E., and LEE-STADELMANN, O.Y. 1980. Effect of freezing deep supercooled water on the viability of ray cells. Botanical Gazette 14:464-468.

HUBERMAN, M.A. 1943. Sunscald of eastern white pine, Pinus strobus L. Ecology 24:456-471.

KOLB, K.J., and DAVIS, S.D. 1994. Drought tolerance and xylem embolism in co-occurring species of coastal save and chaparral. Ecology 75:648-659.

KRAMER, P.J., and KOSLOWSKI, T.T. 1960. Physiology of trees. New York: McGraw-Hill Book Company Inc.

KREBS, C.J. 1999. Ecological methodology. Menlo Park, California: Benjamin/Cummings.

KUBLER, H. 1983. Mechanism of frost crack formation in trees: A review and synthesis. Forest Science 29:559-568.

- - - 1987. Origin of frost cracks in stems of trees. Journal of Arboriculture 13:93-97.
LEVITT, J. 1980. Responses of plants to environmental stresses. New York: Academic Press.

LITZOW, M., and PELLETT, H. 1983. Materials for potential use in sunscald prevention. Journal of Arboriculture 9:35-38.

MAGNANI, F., and BORGHETTI, M. 1995. Interpretation of seasonal changes of xylem embolism and plant hydraulic resistance in Fagus sylvatica. Plant, Cell and Environment 18:689-696.

MOSHER, D.G., and COOL, R.A. 1974. Protective paint induces canker formation. Arborist's News 39:42-44.

NEELY, D., and HIMELICK, E.B. 1987. Freeze-crack-related measurements on Platanus $x$ acerifolia trees. Forest Science 33:239-244.

SAKAI, A., and LARCHER, W. 1987. Frost survival of plants. Berlin: Springer-Verlag.

SAKAI, A., and WEISER, C.J. 1973. Freezing resistance of trees in North America with reference to tree regions. Ecology 54: $118-126$.

SAS INSTITUTE INC. 1998. Statview. Cary, New York: SAS Institute Inc.

SAVAGE, E.F. 1970. Cold injury as related to cultural management and possible protective devices for dormant peach trees. HortScience 5:425-428.

SIMINOVITCH, D., and SCARTH, G.W. 1938. A study of the mechanism of frost injury to plants. Canadian Journal of Research 16:467-481.

SPERRY, J.S. 1993. Winter xylem embolism and spring recovery in Betula cordifolia, Abies balsamifera, and Picea rubens. In: Raschi, A., Borghetti, M., and Grace, J., eds. Water transport in plants under climatic stress. Cambridge: Cambridge University Press. 86-98.

SPERRY, J.S., and SULLIVAN, J.E.M. 1992. Xylem embolism in response to freeze-thaw cycles and water stress in ring-porous, diffuse porous, and conifer species. Plant Physiology 100: $605-613$.

SPERRY, J.S., NICHOLS, K.L., SULLIVAN, J.E.M., and EASTLACK, S.E. 1994. Xylem embolism in ring-porous, diffuse porous, and coniferous trees of northern Utah and interior Alaska. Ecology 75:1736-1752.

TATLER, T.A. 1989. Diseases of shade trees. San Diego: Academic Press, Inc.

VASIL'YEV, I.M. 1956. Wintering of plants (Translated from Russian). Washington, D.C.: American Institute of Biological Sciences.

WEISER, C.J. 1970. Cold resistance and injury in woody plants. Science 169:1269-1278.

WINER, B.J. 1971. Statistical principles in experimental design. Englewood Cliffs, New Jersey: Prentice-Hall, Inc.

ZAR, J.H. 1984. Biostatistical analysis. Englewood Cliffs, New Jersey: Prentice-Hall, Inc. 